\title{
Disaster Alert Village as a Measure of Minimizing Landslide Risks at Alamendah Village
}

\author{
${ }^{1}$ NEINY RATMANINGSIH, ${ }^{2}$ AIM ABDULKARIM, \\ ${ }^{3}$ DINA SITI LOGAYAH, ${ }^{4}$ MAULIA D KEMBARA
}

${ }^{1234}$ Faculty of Social Science Education, Indonesia University of Education, Dr Setiabudhi St. No. 229 Bandung
emails: ${ }^{1}$ neiny@upi.edu, ${ }^{2}$ aimabdulkarim@upi.edu, ${ }^{3}$ dina.logayah@upi.edu, ${ }^{4}$ maulia.depriya@gmail.com

\begin{abstract}
As a factor that can cause landslides, human activities play a vital role in triggering landslides. In West Java Province, unstable soil conditions and environmentally unsound development, coupled with high rainfall are among other factors that most frequently trigger langslides. Measures to overcome the risks can be done by developing a disaster alert village, as part of community participation. The objective of the present research is to discover the community knowledge and attitudes and the level of community participation in minimizing the risk of landslides. A mixed method was adopted. Findings reveal that the village of Alamendah is in an intermediate landslide zone, i.e., land movement occurs when rainfall is above normal, especially in areas bordering river valleys, swamps, road cliffs or slopes. The level of knowledge of the village community in landslide-prevention efforts remains relatively low.
\end{abstract}

Keywords: landslides, disaster alert village, Alamendah community.

\section{Introduction}

Indonesia is the country most vulnerable to natural disasters, with various types of disasters in the world. Geologically, Indonesia is located within a ring of fire (Pacific fire ring) rending the country with frequent earthquakes and volcanic eruptions. About 13 percent of the world's volcanoes are in the Indonesian archipelago, and all have the potential to cause natural disasters with varying intensity and strength. According to the UN report, Indonesia was ranked 4th as the most vulnerable country affected by natural disasters. Worse yet, Indonesia also suffers from so-called social disasters, those caused by humans, i.e., natural exploitation which may trigger disasters. Population density may serve to justify the need for exploiting the environment (Suriadi, Arsyad, \& Riadi, 2013 p. 58)

Development in Indonesia itself tends to center around economic interests by ignoring socio-cultural and environmental aspects. In fact, according to (S, M. Belanawena 2016 p. 300), the development paradigm now focuses on governance in the realm of public administration, international political economy and anthropological sociology, also known as social and political discourse. Beyond that, environmental issues such as disasters continue to arise, e.g., floods, landslides, municipal waste, scarcity of clean water and riverbank abrasion.

Landslides may be caused by rainfall, deforestation, land steepness, agricultural activities, land clearing, and environmentally unsound developments. According to (Pareta \& Pareta, 2012 p. 91), the occurrence of geological landslides can be explained as follows: water that seeps into the soil will increase soil weight. If the water penetrates to the water-resistant soil which acts as a slip plane, the soil will become slippery and the weathering soil above will move along the slope and out of the slope. With that incident, a landslide occurs.

According to the Geological Agency in October 2017, 845 landslides occurred in all regions of Indonesia. The most prominent occurrence of landslides occurred West Java Province with a total of 154 incidents, and the highest number of fatalities was in East Java with 41 deaths. Not long ago, in the early stages of the rainy season, a land disaster

Received: April 15, 2018, Revision: September 15, 2018, Accepted: December 11, 2018

Print ISSN: 0215-8175; Online ISSN: 2303-2499. DOI: http://dx.doi.org/10.29313/mimbar.v34i2.3765.423-433

Accredited B based on the decree No.040/P/2014, valid on February, 18, 2014 until February, 18, 2019. Indexed by DOAJ, Sinta, IPI 
also occurred in Pangandaran, Tasikmalaya, Cianjur, and part of Bandung Regency which resulted in displaced victims. The type of landslide that occurs in West Java Province generally ranges from a slow type which damages houses to a fast type which causes death or loss of life to residents living in landslide-prone areas. The West Java Province is one of the provinces that experiences the most frequent landslides, which can be caused by high rainfall and land conversion in a number of areas. This is worsened by volatile land conditions and development that is not environmentally sound (Amran, 2016, p. 142).

Disaster preparedness is a solution to the community participation approach reducing the loss of lives and properties in the form of a disaster alert village. A communitybased approach is pivotal since the community is the crucial actor during the rescue process when a disaster reaches a recovery stage. On the other hand, the people (especially those living in disaster-prone areas) are the most vulnerable to being victims of disasters. This implies that efforts to increase the capacity for participation and solidarity among the community and the means of participation are increasingly needed. To this end, the Ministry of Social Affairs has facilitated the establishment of a community participation forum called the Disaster Alert Village (DAV). Community participation in dealing with disaster problems, especially landslide disasters, is vitally important. This can be seen from two forms, namely; vertical community participation that is a form of certain vertical conditions in the community involved in it and horizontal participation where the community cannot have initiatives where each community member participates horizontally between each other in cooperating and conducting activities with other parties. Of course, community participation provides a goal from the moment the community is formed and develops independently (Amran, 2016, p. 143).

The objectives of the establishment of Disaster Alert Village according to the Technical Guidelines for Disaster Preparedness Village (DAV) (p. 9) are to: (1) provide public understanding and awareness about disaster hazards and risks; (2) establish community-based disaster alert networks and strengthen social interaction among community members; (3) organizing trained disaster prepared communities; (4) guarantee the implementation of sustainable community based disaster preparedness; (5) optimize potential and resources for disaster management. The central principle of implementing disaster preparedness villages is prioritizing community independence in the face of disasters. In addition, the village disaster preparedness activities emphasize the importance of community preparedness in the face of disasters. Community-based disaster management is in the hand of all parties, not just the government. A community is the target of the first party who is directly faced with threats and disasters. Therefore, community preparedness determines the size of the impact of disasters in the community.

Geographically, the district of Rancabali, Bandung District, especially Alamendah Village, which is the entrance gate for tourists in the South Bandung region is prone to landslides. Geomorphologically, it is in the highlands with an altitude between 1,3002,350 masl, with an area of 505.6 ha and consists of five hamlets (Bappeda, $2016 \mathrm{p}$. 150). Geomorphologically, it is in the highlands with an altitude between 1,300-2,350 masl, with an area of 505.6 ha and consists of five hamlets (Bandung Regency Regional Planning Agency, p. 150). The geographical location of the village of Alamendah is quite strategic because the Ciwidey road, a provincial road, runs through it. The distance from Alamendah village to Rancabali District is around $8 \mathrm{~km}$, which can be reached by vehicles for 15 minutes. The distance from the village to the capital city of Bandung Regency is around $27 \mathrm{~km}$ or approximately one-hour drive and the distance from the village to the provincial capital city of Bandung is $47 \mathrm{~km}$ or around the two-hour drive. Alamendah Village is touristic because of its cool climate and tourist attractions that attract tourists.

Beyond the diversity of touristic sites found in Alamendah village, there is the danger of landslides, resulting from human activities that are not environmentally responsible. For the sake of the fulfillment of economic needs and earning profit, local communities build tourism areas and tourism activities around landslide-prone areas. In addition, they establish steep slope settlements and conduct deforestation on slopes that can accelerate landslides. This suggests that the village of Alamendah is now an area where tourism development is not environmentally sound, and land use is in appropriately managed. With these conditions, the risks of landslide disasters at the village of Alamendah are around the corner. 
The Disaster Alert Village (DAV) modeling concept is a formal forum for communitybased disaster management aimed at increasing the capacity of the community by using the potential and resources available to the community in the face of disasters. DAV seeks to assess the management of the environment and can change patterns of vulnerability and disaster hazards, namely: a) land use planning in managing disaster risk such as controlling population growth, economic plan, and appropriate land use; b) establish safe buildings and protect the most important facilities; c). financial and economic devices and d) early warning system to reduce number of casualties and property. Therefore, the community becomes the elements in all disaster prevention strategies (Amran, 2016 p. 143).

This study aims to determine the level of community participation by using the concept of Disaster Alert Village as mandated in the technical guidelines of Ministry of Social Services (Mineral, 2011), and strives for reducing the risk of landslides. These efforts encompass, i) description of community participation level in efforts to organize landslide disaster risk management, ii) designing a village disaster alert program in Alamendah to prevent landslides; and iii) description of the disaster alert model in Alamendah.

\section{Research Methods}

This research adopted a mixed method, a type of research combining qualitative and quantitative methodologies. According to Sugiyono (2015, p. 253), a mixed method is a study that combines qualitative and quantitative methods in a research activity so that a comprehensive, reliable, objective and valid data is obtained. Through this approach, the obtained information can be more focused and in depth. The mixed method was carried out in a descriptive way to delineate the potential risk of landslides in the village of the Rancabali District, Bandung Regency.

A sequential mixed method was primarily used, more specifically a sequential exploratory strategy. At the initial stage, collecting and analyzing quantitative data was carried out to assess the level of community participation in landslide disaster risk management, and at the second stage, qualitative data of landslides were collected and analyzed. Finally, the model of the village prepared for landslides in Alamendah village was proposed.

The social situation or phenomenology used in this study is the activities of Alamendah villagers in utilizing their residential environment to avoid landslides. The subjects in this study are Alamendah villagers of Rancabali District, Bandung Regency. Consisting of 30 RWs and 112 RTs, there are two RWs in Alamendah that often affected by landslides, namely RW 20 and RW 22 , since geographically they are located on steep slopes. It means only 2 RW are taken as samples with 40 respondents. Data were gathered through interviews, observation, and documentation studies.

Intensive interviews with research subjects were conducted to gather information about their values. In addition, a cross-check was also carried out with other residents. Interviews were conducted using guidelines so that the questions would not deviate from the objectives. Observations were done to directly see the social situation in the local community of Alamendah village. Documentation studies were also carried out to compile secondary sources to complement field results. Data analysis was performed by data categorization, aimed to describe and interpret the data to arrive at a description of the village preparedness for landslides.

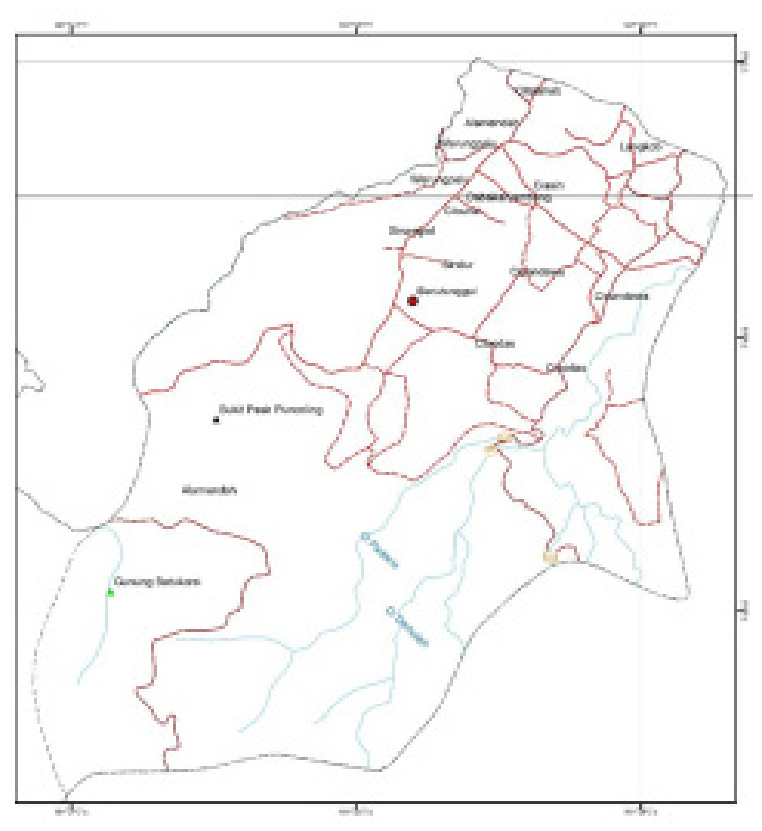

Figure 1. Administrative Map of The Alamendah Village

Source: Rupabumi Map 


\section{Findings and Discussion}

The Alamendah village is located at $7^{\circ} 6^{\prime} 0^{\prime \prime}-7^{\circ} 11^{\prime} 0^{\prime \prime}$ South Latitude and $107^{\circ} 23^{\prime} 0$ "$107^{\circ} 27^{\prime} 0^{\prime \prime}$ East Longitude. Geographically, the village is part of Rancabali District, Bandung Regency, which borders Paninggal Village, Ciwidey District in the North, Sugihmukti Village Pasirjambu District in the East, Patengan Village, Rancabali District in the South, and Lebakmuncang Village Ciwidey District in the West as presented in the figure 1.

Alamendah Village has soil types of Brown Andosol Association, Gray-Brown Regosol, and Litosol Regosol Complexes with reddish brown and slightly sandy physical characteristics (Bappeda, 2016, p. 75). The Association of Brown Andosols and Brown Regosols occurs when there are two types of soil namely Brown Andosols and Brown Regosol in a soil map unit. This condition illustrates that one type of soil does not reach $75 \%$. According to Darmawijaya (Soil Classification, p. 40, 2014), the Gray Regosol and Litosol land complexes are collections of land of different types, mingling with each other in delineation units (map units) without showing specific patterns or showing irregular patterns. Andosol soil itself is a dark red soil, that is very porous and contains organic matter and amorphous type clay, especially Alofan and a little silica, alumina or ironhydroxide. Andosol has a pH of 4.5-6 with organic matter between $8 \%$ to $30 \%$ at the $\mathrm{A} 1$ horizon. Besides, Andosol has mineral content in the form of fine dust and sand fractions in the form of volcanic soil, with ferromagnetic minerals, and clay fractions.

Thus, Andosol soil is classified as fertile and good for agriculture because of its organic matter content and not too acidic $\mathrm{pH}$. Soil Regosol generally does not form nonmaterial materials such as sand, dust, rocks, and gravel, so that it is sensitive to erosion. Regosol type soil is fertile for agriculture, but it requires maintenance, such as mechanical and chemical soil erosion to increase the pore space in the soil and to provide the elements needed by plants such as N, P, and $\mathrm{K}$. Litosol soil has a shallow parent material of approximately $45 \mathrm{~cm}$ with the appearance of solid rock solid integrated soil. In the process, the Litosol soil has not experienced the development of soil for a long time due to the influence of a low climate, volcanic eruption, or topography that is too tilted or wavy.

The slopes in Alamendah village are quite varied starting from the slope to very steep part, as seen on the slope map below that the slope is $8-15 \%$ which shows the sloping slope dominates in the village and almost spread throughout the hamlets, especially in hamlet I, IV, and V. The majority of the slopes is being used as residential land and public facilities that have been engineered with cut and fill system. Slope of $>45 \%$ is not enough in this village, including in hamlet II and protected forest areas owned by Perhutani which are not used for general activities including agriculture. The majority of land for moor and vegetable fields is on a slope of $15-25 \%$ which shows a rather steep slope and $25-45 \%$ indicates steep slope. The fields' locations of human activities are planted with various vegetable commodities by planting directly on the land and using soil media in the container. The slope is rather steep and the variation of steepness results in natural scenery with beautiful impression. So, can be see in the figure 2 about slope steepness of the Alamendah village.

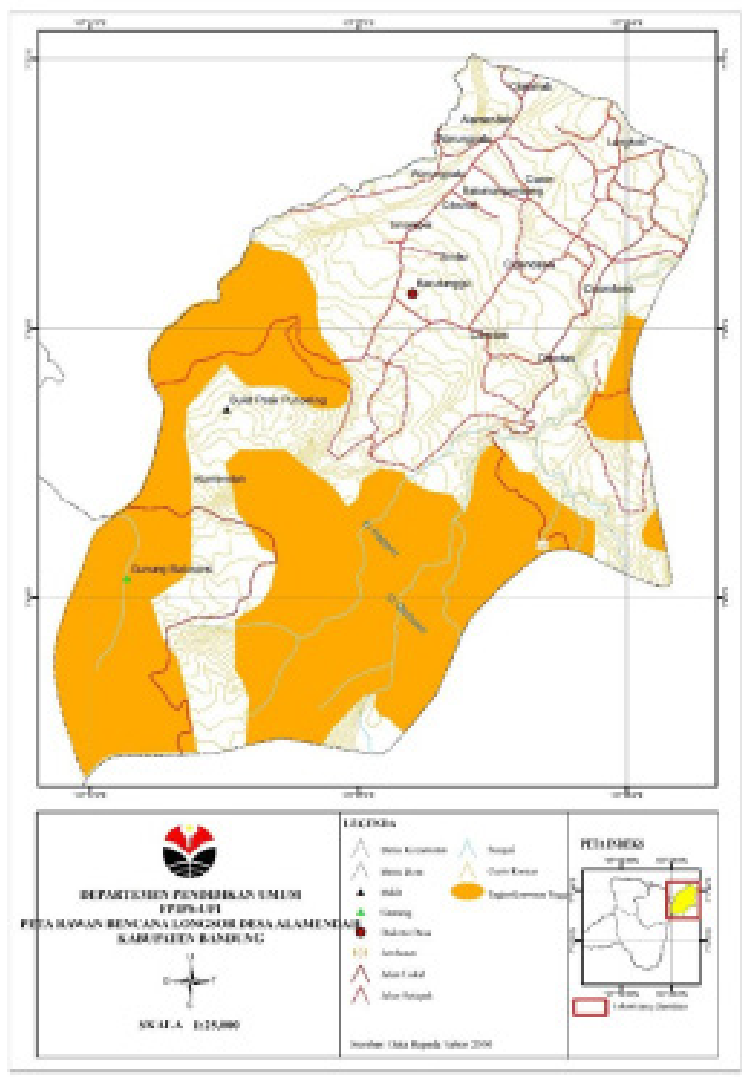

Figure 2. The map of slope steepness of the Alamendah village

Source: Rupabumi of map

The classification of prone to landslides classes in West Java, especially Bandung Regency, according to data from Geological Agency in 2017, in the Table 1. 
Table 1

Landslide Prone Areas

\begin{tabular}{|c|c|c|c|c|}
\hline No & Regency / City & Province & District of & $\begin{array}{c}\text { Occurrence of Ground Motion } \\
\text { Potential }\end{array}$ \\
\hline \multirow[t]{25}{*}{1} & \multirow[t]{25}{*}{ Bandung } & \multirow[t]{25}{*}{ West Java } & Arjasari & $\begin{array}{l}\text { Middle - high, } \\
\text { Floods potential /flow of loosened } \\
\text { component }\end{array}$ \\
\hline & & & Baleendah & Middle- high \\
\hline & & & Banjaran & $\begin{array}{l}\text { Middle- high, flood } \\
\text { Potential of heavy flood (bandang) / } \\
\text { flow of loosened component }\end{array}$ \\
\hline & & & Cicalengka & Middle- high \\
\hline & & & Cikancung & Middle- high \\
\hline & & & Cilengkrang & Middle- high \\
\hline & & & Cileunyi & Middle- high \\
\hline & & & Cimaung & $\begin{array}{l}\text { Middle- high, } \\
\text { Floods potential / flow of loosened } \\
\text { component }\end{array}$ \\
\hline & & & Cimenyan & $\begin{array}{l}\text { High- high, } \\
\text { Floods potential / flow of loosened } \\
\text { component }\end{array}$ \\
\hline & & & Ciparay & Middle- high \\
\hline & & & Ciwidey & $\begin{array}{l}\text { Middle - high, } \\
\text { Floods potential / flow of loosened } \\
\text { component }\end{array}$ \\
\hline & & & Ibun & $\begin{array}{l}\text { Middle - high, } \\
\text { Floods potential / flow of loosened } \\
\text { component }\end{array}$ \\
\hline & & & Kertasari & $\begin{array}{l}\text { Middle - high, } \\
\text { Floods potential / flow of loosened } \\
\text { component }\end{array}$ \\
\hline & & & Kutawaringin & Middle- high \\
\hline & & & Majalaya & $\begin{array}{l}\text { Middle, Floods potential Material / flow } \\
\text { of loosened component }\end{array}$ \\
\hline & & & Margaasih & Middle - high \\
\hline & & & Nagreg & Middle- high \\
\hline & & & Pacet & Middle - high \\
\hline & & & Pameungpeuk & Middle- high \\
\hline & & & Pananjung & $\begin{array}{l}\text { Middle - high, } \\
\text { Floods potential / flow of loosened } \\
\text { component }\end{array}$ \\
\hline & & & Pangalengan & Middle - high \\
\hline & & & Paseh & Middle- high \\
\hline & & & Pasir jambu & $\begin{array}{l}\text { Middle - high, } \\
\text { Floods potential / flow of loosened } \\
\text { component }\end{array}$ \\
\hline & & & Rancabali & $\begin{array}{l}\text { Middle - high, } \\
\text { Floods potential / flow of loosened } \\
\text { component }\end{array}$ \\
\hline & & & Soreang & $\begin{array}{l}\text { Middle - high, } \\
\text { Floods potential / flow of loosened } \\
\text { component }\end{array}$ \\
\hline
\end{tabular}

Source : Geological Agency of Indonesia, 2017 
The map and the table above indicate that the Rancabali area has the potential for landslides in the medium to high probability. According to the Geology Agency in the Table 2 , this means that:

\section{Table 2 \\ Zone Criteria of Landslide Vulnerability}

\begin{tabular}{|l|l|}
\hline Middle & $\begin{array}{l}\text { This area has the middle potential } \\
\text { for land movement. Land movement } \\
\text { occurs when rainfall is above } \\
\text { normal, especially in the areas } \\
\text { bordering river valleys, swamps, } \\
\text { road cliffs that are destroyed. }\end{array}$ \\
\hline High & $\begin{array}{l}\text { This area has the middle potential } \\
\text { for land movement. Land movement } \\
\text { occurs when rainfall is above } \\
\text { normal, and movement of old land } \\
\text { can occur again. }\end{array}$ \\
\hline
\end{tabular}

Source: Geological Agency of Indonesia, 2017

The physical geography analysis of the village of Alamendah reveals that the varying slope steepness is a factor for the potential risk of landslides in Alamendah. This risk can be prevented by doing soil and water conservation, which can be done in two methods, namely the mechanical and vegetative methods (Juhadi, Wahyu and Nia, 2016 p. 2017). Mechanical methods can be carried out by applying contour (terraced) planting patterns, irrigation improvements, and drainage, while the vegetative method can be carried out by planting type of plants that are continuously covering the soil or by rotating crops.

The Alamendah Village itself has applied both methods, but consistency and totality in applying them in order to avoid the risk of landslides is a work in progress. The process of landslides can be caused as follows; water seeps into the soil that increases the weight of the soil. When the water penetrates into the water-resistant soil which acts as a slip plane, the soil becomes slippery, and the weathering soil on it will move along the slope and out of the slope. In principle, landslides occur when the driving force on the slope is greater than the retaining force. Retaining forces are generally influenced by rock strength and soil density, while the driving force is influenced by the magnitude of the slope angle, water, load, and rock soil specific gravity. The steeper the slope angle of an area, the greater the likelihood of a landslide.

In addition, agricultural activities and cultivation should be oriented towards nature and consistent in maintaining sustainability. Following in the figure 3 abaout map of land use the Alamendah village.

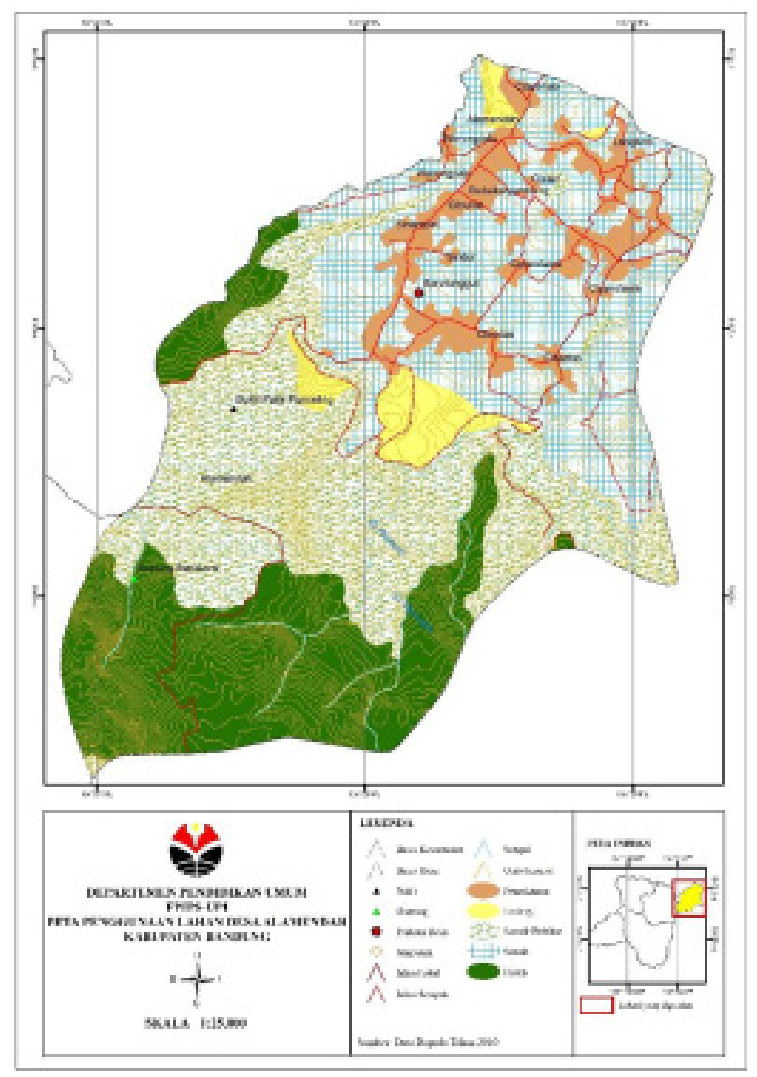

Figure 3. Map of Land Use in Alamendah Village

Source: Rupabumi Map

The Regulation of the Head of the National Disaster Management Agency (BNBP) number 4 of 2008 prescribes that the community is the initial actor in dealing with disasters as well as disaster victims; they must be able to handle certain disasters so that disasters do not develop into a larger scale. The community also needs to understand efforts to face the risk of landslides that can threaten their lives, i.e., increased potential for landslides due to an increase in population and activities of the community in managing the environment. This means that public awareness of efforts to reduce landslide risks is paramount.

This study seeks to measure the level of knowledge of the village community of Alamendah regarding disasters, especially landslides. In measuring public knowledge, several indicators are relevant, namely: (a) knowledge of disaster risks; (b) attitudes about disaster risks; (c) availability of facilities and infrastructure during a disaster; (d) existence of a disaster organization or institution; (e) threat level and landslide risks, 
(f) landslide risk reduction behavior. These seven indicators can be described as follows:

Knowledge about disaster risk; what is relevant in this indicator is the knowledge of the people of the village of Alamendah about natural disasters, types of natural disasters, landslides, and the impact of landslides. The following are the results regarding the community knowledge of the disasters in the village of Alamendah. Of the 40 respondents, $62 \%$ already knew the meaning of disasters and landslides; $25 \%$ did not understand the meaning of disasters and landslides and $13 \%$ had no idea what the disasters are. It can be concluded the community knowledge about disasters and landslides is reasonably high.

Attitudes about disaster risk concern itself with the community's attitude towards landslides. This attitude correlates with the knowledge of the villagers regarding disasters. Around $30 \%$ of the people perceived that disasters must be responded responsibly because disasters can threaten their lives and damage the properties they have. About $42 \%$ still have a normal attitude related to disasters, for they believed natural disasters might strike at any time, so the most important thing is how they protect the environment.

Availability of facilities and infrastructure is crucial in the event of a disaster because when a disaster strikes the community, the facilities and infrastructure are a first priority in the aftermath of the disaster. The role of the local government or the Alamendah village office must at least facilitate the availability of facilities and infrastructure. Data indicate that the post-disaster facilities and infrastructure in the village are yet sufficient; as reported by around $75 \%$ of the respondents. What is available is merely an evacuation route to a safe place if a disaster occurs. Around 25\% of the respondents stated that no facilities and infrastructure are available at all. This correlates with the attitude of the people who do not care about the disaster in Alamendah.

The presence of a disaster alert organization is vital in the community to help provide education, socialization, and training on disasters. Findings indicate that there are no institutions or organizations related to post-disaster, such as providing counseling and socialization to the community, especially the 2 RWs that are often hit by landslides.

In terms of threat and disaster risk levels, the vulnerability for landslides resides at the level of $65 \%$ or in the middle/medium zone. The middle zone is a movement zone of landslides that can occur in areas in the border areas of river valleys, swamps or cliffs. The landslide is caused by high rainfall. The two RWs which are often hit by landslides are located around swamps or cliffs which have steep contours.

Concerning Disaster Risk Reduction Behavior, data reports that $38 \%$ of the behavior of the Alamendah community against the occurrence of landslides remains at a moderate level and $50 \%$ at a low level. This can be caused by the absence of real support from the local government. The community is insensitive to the environment by living or settling in the landslide-prone zone.

Based on the results, there is apparently a positive relationship between the knowledge and the behavior of the villagers of Alamendah towards the occurrence of landslides. The knowledge of the local community is still relatively low in understanding the landslide disaster. Hence, the risk of landslides with property damage and casualties is relatively high. DAV emphasizes the importance of disaster preparedness and educates the local community about disasters. With this, the community can plan and take necessary measures to reduce the consequences of a disaster. This confirms Amran's (2016, p. 149) finding that the low public knowledge about landslide disaster risk points to low public awareness, lack of information exchange, lack of education and disaster management training, lack of cultural support toward disaster preparedness, and poor attitude and community motivation in disaster management (Amni, 2017, p. 3).

Nevertheless, landslides are unpredictable so that preparedness in facing disasters does not suffice. A DAV team is crucial to prepare activities before, during and after a disaster. Activities prior to a disaster focus on the introduction of potential and resources available to the community, threats and disaster risks that may arise as a result of a disaster event and prepare the community at any time in the event of a disaster (preparedness). Community preparedness before a disaster is vitally important, considering that disasters can occur at any time (Nugroho, Hero, \& Ambar, 2013, p. 381-382). In the event of a disaster, the DAV Team focuses on providing direct assistance to disaster victims, namely practicing what has been prepared before the 
disaster. The head of the DAV team decides whether the villagers are to be displaced or not and who should be contacted in the event of a disaster.

In this study, the village disaster alert modeling was carried out through several stages, namely the pre-disaster, emergency and post-disaster stages. The stages are explained below.

The preliminary stage is an activity performed in a situation before a disaster occurs and in a situation where there is the potential for a landslide. This activity can be done to reduce disaster risks, both through reducing the threat of disasters and the vulnerability of parties threatened by disaster. In this study, the modeling sites under investigation were RW 20 and 22 since these are often hit by landslides. The two RWs are situated in the middle zone of ground movement vulnerability which is an area bordering river valleys, swamps, cliff cutting roads, and slopes that have experienced physical changes. This pre-disaster activity begins with the provision of information on landslides by looking for data or previous research on landslide safety zone maps and landslide baseline data regarding the location, events and research data from the Geological Agency for the land movement mitigation sub-sector. After data collection, a mapping of the ground movement vulnerability zone was created, and the result was a disaster risk mapping of the landslide movement. After the landslide risk map was generated, a landslide awareness campaign began to be started for the community of Alamendah. The speaker for the event was a practitioner and researcher from the Geological Agency for the ground movement mitigation sub-sector, i.e., Anjar $\mathrm{H}, \mathrm{ST}, \mathrm{MT}$. The socialization event was carried out for two days in the Alamendah village office. Afterward, the instrument to measure knowledge of landslide risks and preparedness of DAV was disseminated. Can be see figure 4 about socialization event of lindslide risk.

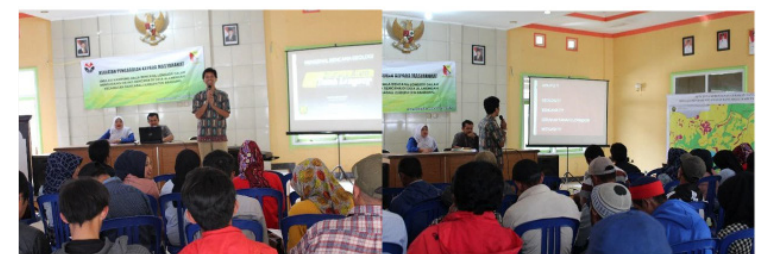

Figure 4. Socialization event of landslide risks

Source: Personal documentation, 2017

The second stage was an emergency response, i.e., is an activity when the landslide disaster occurs. The DAV program enables the community to be more independent in facing landslides. This is done to minimize potential disaster risks, both through reducing threats and the vulnerability of parties threatened by the disaster. In this respect, the government's role is to investigate the causes, mechanisms, potential threats of subsequent landslides, impacts and the spread of landslides. The results of the investigation are outlined in technical recommendations for mitigation measures and the restoration of facilities and infrastructure. Finally, the last stage was post-disaster, i.e., a post-disaster activity to be carried out in a situation after the disaster occurs. Post-disaster is closely related to recovery activities. During the recovery period, it is better for the management and members of the DAV to hold regular meetings with other community members to find out the needs and recovery methods for the impact of the disaster. The following is an diagram 1 illustration of the stages of modeling the DAV in Alamendah village.

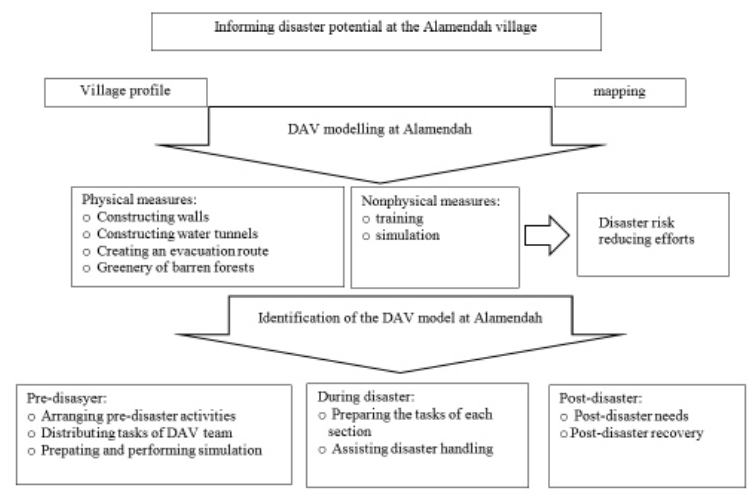

Diagram 1. Modeling stages of DAV of Alamendah - 2017

Source: Modification of the technical guidelines of the Ministry of Social Affairs and findings of previous research of 2011

The community participation in the face of landslides in the village of Alamendah is still relatively low. This is because, despite some knowledge of disasters the community has, real actions in the community are still lacking. This can be influenced by the lack of awareness of environmental preservation. The village of Alamendah has potential as an agrotourism, and the livelihoods of its residents still rely on farming and plantation systems.

The community has become one of the most critical elements (Juhadi, Wahyu, 2016 p. 221). It serves as the heart and leading 
actor in disaster management, especially during the rescue process if a disaster occurs at the time of recovery. On the other hand, the community, especially those who live in disaster-prone areas, are the most vulnerable to being victims of disasters. In order to optimize the involvement of the community, the problem that needs to be addressed is how to ensure the effectiveness of participation itself. This condition necessitates measures to enhance the capacity of participation and solidarity among the community and an increasingly necessary forum for participation such as activities or implementation of the Disaster Alert Village (DAV).

Based on the results of the study, the low level of public knowledge about landslide disaster risk indicates that community participation is still low. Knowledge of landslide risks is a critical factor so that leaders and community members can make the right decisions in accordance with the characteristics and needs of the community. The formation of the DAV at the RW and Subdistrict level was due to the increased awareness of the disaster management following the landslide disaster, with increasing public awareness of the participation of the community in Alamendah before and after the DAV was formed. This can be seen from the community participation in such measures as waste management, household wastewater disposal, and management of agricultural land that gradually conforms to environmentally sound principles.

Community measures that can be taken to avoid the occurrence of landslides, according to Arisanti \& Wisnu (2018) are as follows: make terraces on steep land. Most of the local community's livelihood is farming. One of the agricultural activities is vegetables. Various conditions of land are used for this activity, one of which is steep hills. When the dry season arrives, the surface soil becomes dry, as a result, the soil solidifies and cracks occur. If the crack is found in the cliff area, of course, the land is not bound. Eventually a landslide takes place. To avoid landslides, we must fill in the cracks in the soil to stabilize it so that landslides do not occur. In this way, the land will be bound again. Cutting trees or destroying forests is an obvious example of land mismanagement that can also lead to disasters. If during the greening stage, a landslide can occur. For this reason, the community of Alamendah is encouraged not to do logging or destruction of the forest in any way because the forest functions as a natural water reservoir. If this function ceases, then the rainwater that falls on a mountainous or hilly slope will slide swiftly into the lower regions resulting in a landslide.

Planting strong rooted plants such as acacia, banyan, bamboo, vetiver, and lamtoro on the barren slopes to prevent landslides from occurring can be an effective measure because strong plant roots on steep slopes can hold water while binding soil grains so that landslides can be prevented (Choi \& Cheung, 2013, p. 300). Making rainwater channels is another alternative to prevent landslides. Making rainwater can be done in residential areas or on slopes used for rice fields and cultivation. With the rainwater channel, when it rains the water will flow directly to the channels so that it does not erode the surrounding soil. Building retaining walls on slopes that are steep is also another mitigation effort to prevent landslides; communities can jointly build retaining walls on steep slopes (Namdar \& Yahaya, 2014, p. 1524). The steep slope is an area prone to landslides. Checking the condition of the land regularly can be done by the community. By checking this type of periodic checking, one can quickly detect whether or not the land is in a damaged condition. With early identification of the condition of the land, preventive measures can be carried out as soon as possible.

\section{Conclusion}

The Disaster Alert Village measures underscore the importance of community preparedness in the face of disasters. With this, the community can plan an action to reduce the consequences of a disaster. Community participation in dealing with landslides in the Alamendah village was still relatively low largely because, despite the community knowledge of disasters they have, real actions in the community are still lacking. This may be influenced by the lack of people in environmental preservation. The village of Alamendah has the potential as an agrotourism, and the livelihoods of its residents still rely on agricultural and plantation systems.

Several conclusions can be drawn as follows: the implementation disaster alert villages (DAV) in disaster-prone areas took place only at 2 RWs of 30 RWs in the village, for these were most vulnerable to landslides and the danger level of landslides was middle. 
The physiographic form of the village area and the ecological support provide a good correlate between the population activities and the ability of the people of Alamendah to respond to landslides. This condition is supported by the fact that the village of Alamendah is the gateway to South Bandung. Landslides can sometimes not be intervened with technology or other engineering efforts because the landslide-prone areas are very steep and there is no access to get there. DAV can serve as a viable solution to prevent any disaster from happening.

\section{References}

Amni, U. (2017). Jurnal Ilmu Sosial Jurnal Ilmu Sosial, 16 (1), 1-8.

Amran. (2016). PEKSOS: Jurnal IImiah Pekerjaan Sosial Vol.15 No.1, Juni 2016. Peksos, 15(1).

Arisanti, Y., \& Wisnu, P. (2018). Strategi Manajemen Bencana di Kabupaten Magelang, 1 (4), 2012.

Bappeda. (2016). Badan Perencanaan Daerah Kabupaten Bandung. Bandung: Bappeda Kabupaten Bandung.

Choi, K. Y., \& Cheung, R. W. M. (2013). Journal of Rock Mechanics and Geotechnical Landslide disaster prevention and mitigation through works in Hong Kong. Integrative Medicine Research, 5(5), 354-365. https://doi.org/10.1016/j. jrmge.2013.07.007

Darmawijaya. (2014). Klasifikasi Tanah. Yogyakarta: Gajahmada University Press.

Juhadi, Wahyu, N. (Unnes). (2016). Jurnal Geografi, 13 (2), 216-224.
Mineral, M. E. (2011). Pedoman Mitigasi Bencana Gunungapi, Gerakan Tanah, Gempabumi dan Tsunami. Jakarta: Kementerian Energi dan Sumber Daya Mineral.

Namdar, A., \& Yahaya, F. M. (2014). Effect of Natural Hazards on Types of Landslide, 1519-1532.

Nugroho, Prasetyo and Soedjoko, Sri Astuti and Kusumandari, Ambar and Marhaento, Hero (2013). Adaptasi dan Mitigasi Bencana Tanah Longsor Melalui Penguatan Kapasitas Masyarakat dan Peningkatan Produktivitas Lahan melalui Sistem Agroforestri. Prosiding Seminar Nasional Agroforestri (hal. 380-385). Yogyakarta: Gajahmada university Press.

Pareta, K., \& Pareta, U. (2012). Landslide Modeling and Susceptibility Mapping of Giri River Watershed, Himachal Pradesh (India), 1(2), 91-104.

Sugiyono. (2015). Metode Penelitian Kuantitatif Kualitatif dan R\&D. Bandung: Alfabetha.

S, M. Belanawane. (2016). Kampung Siaga Bencana Sebagai Instrumen Kebijakan Pengurangan Risiko Bencana Berbasis Komunitas Di Indonesia: Politik Pembangunan Dan Partisipasi Dalam Diskursus Disaster-Aware Village As Community-Based Disaster Risk Reduction Policy Instrument in Indon, 5(01).

Suriadi, A. B., Arsyad, M., \& Riadi, B. (2013). Potensi Resiko Bencana Alam Longsor (Potential Risk of Landslide Related to Extreme Weather in Ciamis Region, West Java). Jurnal Ilmiah Geomatika, 19 (1), $57-63$. 